\title{
Implementasi Keterbukaan Informasi Publik di Kabupaten Bantul
}

\author{
Mega Ardina ${ }^{1 *}$ Erni Saharuddin ${ }^{2}$ \\ ${ }^{1}$ Program Studi Komunikasi; ${ }^{2}$ Program Studi Administrasi Publik \\ Universitas 'Aisyiyah Yogyakarta, Yogyakarta, Indonesia \\ *E-mail: mega_ardina@unisayogya.ac.id
}

\begin{abstract}
Every public institution is obliged to implement the Law No.14/2008 on the openness of public information. The study was aimed at identifying to what extent public institutions in Bantul Regency implement public information openness focusing on dissemination of public information by means of official websites. By using qualitative method, the data collection technique applied in this study included evaluation of the websites content followed by observation and interviews. The analysis was done qualitatively based on the collected data, facts, and informations by sticking to representative searching in order to avoid bias. The data was analyzed through coding ten public institutions websites, followed by interpretation. The study showed that the level of public information openness implementation in Bantul Regency reaches $88.4 \%$ which is considered very great. Out of 10 public institutions, two fall into the category of 'good'and reach 77\%, five public institutions fall into the category of 'very good' which reach more than $80 \%$, and three institutions reach perfect score (100\%) which fall into the category of "very good". It shows that public institutions in Bantul Regency have provided proper facilities and infrastructure for the people to access public information in accordance with the principles of 'the Law on the Openness of Public Information.
\end{abstract}

Keywords: implementation, public information openness, public institutions

\begin{abstract}
ABSTRAK
Setiap Badan Publik wajib mengimplementasikan Undang-Undang No. 14 Tahun 2008, tentang Keterbukaan Informasi Publik. Penelitian ini bertujuan untuk mengetahui implementasi Keterbukaan Informasi Publik dari Badan Publik di Kabupaten Bantul, yang berfokus pada penyebarluasan informasi publik dengan memanfaatkan website resmi. Metode penelitian yang digunakan adalah kualitatif dengan teknik pengumpulan data dilakukan melalui penilaian terhadap konten website, kemudian dilanjutkan dengan melakukan observasi dan wawancara. Analisis data dilakukan dengan analisis kualitatif berdasarkan data, fakta, dan informasi yang dikumpulkan dengan tetap mengedepankan penelusuran representatif untuk menghindari data bias. Analisis data dilakukan dengan koding dari 10 website badan publik kemudian dilakukan interpretasi. Hasil penelitian menunjukkan bahwa implementasi Keterbukaan Informasi Publik di Kabupaten Bantul sebesar 88,4\% (sangat baik). Dari 10 Badan Publik, sebanyak 2 Badan Publik masuk dalam kategori baik dengan presentase 77\%, 5 Badan Publik masuk dalam kategori sangat baik dengan presentase di atas 80\%, dan 3 Badan Publik mencapai nilai sempurna yaitu sebesar $100 \%$ dengan kategori sangat baik. Hal ini menunjukkan bahwa badan publik di Kabupaten Bantul telah menyediakan sarana dan prasarana yang memadahi agar masyarakat dapat mengakses informasi publik sesuai dengan asas UU KIP.
\end{abstract}

Kata kunci: Implementasi, Keterbukaan Informasi Publik, Badan Publik

\section{Pendahuluan}

Pasal 28 F UUD 1945 menyebutkan bahwa setiap orang berhak untuk berkomunikasi dan memperoleh informasi untuk mengembangkan pribadi dan lingkungan sosialnya, serta berhak mencari, memperoleh, memiliki, dan menyimpan informasi dengan menggunakan segala jenis saluran yang tersedia. Untuk memberikan jaminan terhadap semua orang dalam 
memperoleh informasi, Indonesia sudah mempunyai regulasi mengenai Infomasi Publik yang tercantum dalam Undan-Undang Nomor 14 Tahun 2008 tentang Keterbukaan Informasi Publik.

Salah satu elemen penting dalam mewujudkan penyelenggaraan negara terbuka adalah hak publik untuk memperoleh informasi sesuai dengan peraturan perundang-undangan. Hak atas informasi menjadi sangat penting karena semakin terbuka penyelenggaraan negara untuk diawasi publik, penyelenggaraan negara tersebut makin dapat dipertanggungjawabkan. Hak setiap orang untuk memperoleh informasi juga relevan untuk meningkatkan kualitas pelibatan masyarakat dalam proses pengambilan keputusan publik.

Perkembangan TIK dewasa ini telah mengubah pola kebijakan informasi dalam sebuah negara, termasuk Indonesia. Informasi bukan lagi sesuatu yang dapat disembunyikan atau dikuasai. Dengan memanfaatkan TIK masyarakat semakin mudah mendapatkan informasi melalui berbagai media. Menurut Nupikso (2015: 114), salah satu asas dalam UU KIP adalah setiap informasi publik harus dapat diperoleh pemohon dengan cepat, tepat waktu, biaya ringan, dan cara sederhana. Hal ini mengandung arti bahwa badan publik harus menyediakan sarana dan prasarana yang memadai agar masyarakat dapat mengakses informasi publik sesuai dengan asas tersebut. Salah satu pilihan yang banyak dilakukan oleh badan publik di lingkungan Pemerintah Daerah (Pemda) baik provinsi, kabupaten/kota dan kecamatan adalah memanfaatkan teknologi informasi dan komunikasi (TIK) melalui jaringan internet dengan memanfaatkan media website.

Pemanfaatan website dikalangan pemerintahan menunjukkan peningkatan yang sangat pesat. Semakin banyak negara di dunia yang memanfaatkan teknologi informasi dan komunikasi untuk memberikan informasi kepada warganegaranya, menyediakan fasilitas transaksi keuangan online, melakukan konsultasi dan edukasi kepada warga negara. Pemanfaatan media dalam rangka publikasi informasi publik dapat dilakukan melalui berbagai cara dan menggunakan berbagai sarana dan prasarana yang ada. Salah satunya yang diwajibkan bagi badan publik negara adalah memanfaatkan website resmi bagi yang telah memiliki. Informasi yang wajib disediakan dan diumumkan secara berkala merupakan jenis informasi publik yang sekurang-kurangnya diumumkan melalui website resmi.

Seringkali keluhan, saran, atau kritik masyarakat sering tidak ditanggapi dengan baik dan benar. Prinsip-prinsip good governance tidak akan terwujud tanpa kepedulian pemerintah daerah untuk menyadari bahwa selama ini pemerintah memiliki kewajiban untuk menyampaikan 
informasi penyelenggaraan pemerintah daerah kepada warga masyarakatnya.

Kabupaten Bantul DIY merupakan salah satu daerah yang wajib mengimplementasikan Undang-Undang No. 14 Tahun 2008, tentang Keterbukaan Informasi Publik. Kewajiban ini menuntut tanggung jawab serta kerjasama yang baik dari Pejabat Pengelola Informasi dan Dokumentasi (PPID) yang menjadi pilar utama, sehingga seluruh badan publik di lingkungan Kabupaten Bantul dapat mengimplementasikan Keterbukaan Informasi Publik dengan baik. Berdasarkan data dari Komisi Informasi DIY pada tahun 2018, belum semua badan publik di Kabupaten Bantul mengunggah informasi yang telah ditentukan oleh UU bahkan sebagian memiliki website resmi. Oleh karena itu, Implementasi Keterbukaan Informasi Publik dari Badan Publik di lingkungan Kabupaten Bantul menjadi penting untuk dikaji.

Berdasarkan hasil penelusuran terkait dengan topik penelitian yang sama dengan penelitian yang akan dilakukan saat ini, ditemukan beberapa hasil penelitian terdahulu yang memiliki persamaan dan juga perbedaan dengan penelitian yang akan dilakukan. Berikut adalah penelitianpenelitian terdahulu yang berhasil ditemukan:

Penelitian pertama yang dilakukan oleh Daru Nupikso (2015:113-128) yang berjudul "Implementasi Keterbukaan E-ISSN: 2580-6955
Informasi Publik dalam Website Pemerintah Daerah". Penelitian ini bertujuan untuk mengetahui implementasi UU KIP dalam website pemerintah daerah dengan menggunakan metode analisis isi. Hasil penelitian menunjukkan bahwa secara umum, kuantitas muatan informasi publik yang ditampilkan dalam website pemerintah masih rendah, meskipun beberapa website memperoleh poin tinggi dalam beberapa indikator. Terdapat perbedaan signifikan dalam perolehan poin antara website yang pernah menerima penghargaan bidang TIK dengan yang belum pernah menerima penghargaan.

Penelitian kedua yang dilakukan oleh Zulaikha dan Paribrata (2017: 131-162) yang berjudul "Implementasi Kebijakan Keterbukaan Informasi Publik di Jawa Timur Tahun 2016" memotret implementasi kebijakan keterbukaan informasi publik di Jawa Timur, yang terdiri atas 38 kabupaten/kota dan 56 Satuan Kerja Perangkat Daerah. Hasil penelitian ini menunjukkan bahwa untuk pemerintah kabupaten atau kota, implementasi kebijakan keterbukaan informasi ini mengalami perkembangan yang menggembirakan, tetapi tidak demikian dengan Satuan Kerja Perangkat Daerah. Demikian juga dengan Pejabat Pengelola Informasi dan Dokumentasi juga mengalami perkembangan meski masih ada kekurangan dalam pelaksanaan tugasnya. 
Penelitian ketiga yang dilakukan oleh Hariyanti (2018:127-139) dengan judul "Implementasi Kebijakan Keterbukaan Informasi Publik pada Dinas Kominfo Kota Tasikmalaya". Penelitian ini mengkaji bagaimana implementasi kebijakan keterbukaan informasi publik yang dijalankan oleh Dinas Komunikasi dan Informatika Pemerintahan Kota Tasikmalaya. Penelitian ini dilakukan dengan menggunakan metode deskriptif kualitatif, dengan pengambilan data melalui wawancara dan observasi langsung baik di kantor Dinas Kominfo Kota Tasikmalaya maupun pada media sosial yang digunakan oleh petugas dalam menyebarluaskan informasi publik. Hasil yang diperoleh adalah faktor-faktor yang dapat mempengaruhi keberhasilan implementasi kebijakan yaitu Faktor Komunikasi, Sumber Daya, Disposisi dan Struktur Birokrasi sudah cukup terpenuhi dengan baik, hanya saja terdapat kendala pada faktor sumber daya yaitu kurangnya jumlah staf seksi pelayanan informasi publik yang merupakan implementor dalam kebijakan tersebut, selain itu belum terpenuhinya fasilitas penunjang seperti kamera profesional. Meskipun jumlah staf yang kurang memadai, implementor memiliki keahlian dalam menjalankan kebijakan tersebut yaitu mampu mengoperasikan website dan juga media sosial sebagai sarana menyebarluaskan informasi publik. Hal tersebut menjadi salah satu penunjang E-ISSN: 2580-6955 keberhasilan implementasi kebijakan yang dijalankan sehingga pada November 2017 Dinas Kominfo Kota Tasikmalaya mendapatkan penghargaan ke-3 pada Anugerah Media Humas 2017 kategori media sosial.

Berdasarkan hasil dari pembahasan terhadap penelitian terdahulu ditemukan kesamaan dan juga perbedaan dengan penelitian yang akan dilakukan oleh penulis. Persamaannya yaitu membahas implementasi keterbukaan informasi publik suatu daerah. Perbedaan penelitian ini dengan penelitian sebelumnya adalah penelitian ini tidak hanya melakukan penilaian dari website, tetapi juga melakukan observasi dan wawancara untuk konfirmasi.

Penelitian ini bertujuan mengetahui Implementasi Keterbukaan Informasi Publik dari Badan Publik di lingkungan Kabupaten Bantul. Penyebarluasan informasi publik dengan memanfaatkan website resmi yang dimiliki oleh badan publik menjadi fokus penelitian ini, karena membangun website yang menyediakan informasi yang benarbenar dibutuhkan oleh masyarakat.

\section{Metode Penelitian}

Penelitian ini menggunakan jenis penelitian deskriptif kualitatif. Penelitian deskriptif menurut Arikunto (2010) yaitu mengumpulkan data berdasarkan faktorfaktor yang menjadi pendukung terhadap objek penelitian, kemudian menganalisa 
faktor-faktor tersebut untuk dicari peranannya. Selain itu, secara harfiah penelitian deskriptif adalah penelitian yang bermaksud untuk membuat pencandraan (deskripsi) mengenai situasi-situasi atau kejadian-kejadian (Suryabrata, 2013).

Adapun teknik pengumpulan data Menurut Koentjoro (2010) dalam penelitian kualitatif dikenal dengan beberapa metode pengumpulan data yang umum digunakan. Beberapa metode tersebut, antara lain wawancara, observasi, studi dokumentasi dan focus group discussion (FGD).

Pada penelitian ini digunakan teknik pengumpulan data melalui penilaian terhadap konten website dan dilanjutkan dengan melakukan observasi dan wawancara. Teknik wawancara sebagai metode untuk melakukan konfirmasi kepada badan publik atas informasi yang disediakan di website.

Lokasi penelitian diambil secara purposive sesuai dengan kebutuhan penelitian yaitu pada 10 badan publik di Kabupaten Bantul yang sudah memiliki website resmi. Adapun sepuluh badan publik tersebut antara lain: Dinas Kesehatan Kabupaten Bantul, Dinas Tenaga Kerja dan Transmigrasi Kabupaten Bantul, Dinas Perdagangan Kabupaten Bantul, BAPPEDA Kabupaten Bantul, Dinas Pertanahan dan Tata Ruang Kabupaten Bantul, Dinas Kominfo Kabupaten Bantul, Dinas Kependudukan dan Pencatatan Sipil Kabupaten Bantul, Dinas Lingkungan Hidup Kabupaten Bantul, Badan E-ISSN: 2580-6955
Pusat Statistik Kabupaten Bantul, dan Pengadilan Agama Kabupaten Bantul.

Peubah yang diamati dalam penelitian ini ialah pada 10 kategori informasi yang wajib disediakan dan diumumkan secara berkala yakni: Profil badan publik, ringkasan program/kegiatan yang sedang dijalankan, informasi kinerja badan publik, ringkasan laporan keuangan, ringkasan akses informasi publik, informasi tentang peraturan, keputusan dan atau kebijakan yang mengikat dan berdampak bagi publik, informasi tentang tata cara memperoleh informasi publik, informasi tentang tata cara pengaduan mengenai penyalahgunaan wewenang, informasi tentang pengumuman pengadaan barang dan jasa, serta informasi tentang prosedur peringatan dini dan evakuasi

Analisis data dilakukan secara analisis kualitatif berdasarkan data, fakta dan informasi yang dikumpulkan dengan tetap mengedepankan penelusuran representatif untuk menghindari data bias. Dalam penelitian ini, analisis data dilakukan melalui tahapan seluruh hasil koding dari 10 website ditabulasi untuk melihat jumlah poin oleh masing-masing website badan publik serta dilakukan interpretasi. Interpretasi dilakukan dengan melihat website yang memperoleh poin yang menonjol kemudian setiap indikator untuk masing-masing website sampel dianalisis secara deskriptif dengan dasar jumlah poin yang diperoleh masingmasing website. 


\section{Hasil dan Pembahasan}

Dengan membuka akses publik terhadap informasi diharapkan badan publik termotivasi untuk bertanggungjawab dan berorientasi pada pelayanan rakyat yang sebaik-baiknya (Arliman, 2018). Pope dalam Nurdiansyah (2016) juga menjelaskan semakin banyak masyarakat mendapatkan informasi, semakin bermakna peran yang mereka mainkan dalam dialog bersama pemerintah dan antar sesama anggota masyarakat.

\section{Menurut Kadji (2015: 48-50),} Implementasi kebijakan publik sebagai salah satu dimensi dalam proses kebijakan publik, yang juga sangat menentukan apakah sebuah kebijakan itu bersentuhan dengan kepentingan serta dapat diterima oleh publik.

Menurut Undang undang Nomor 14 Tahun 2008 tentang Keterbukaan Informasi Publik, Kabupaten Bantul DIY merupakan salah satu daerah yang wajib mengimplementasikan Undang-Undang No. 14 Tahun 2008, tentang Keterbukaan Informasi Publik. Kewajiban ini menuntut tanggung jawab serta kerjasama yang baik dari Pejabat Pengelola Informasi dan Dokumentasi (PPID) yang menjadi pilar utama. Mengacu pada UU No. 14 tersebut, hasil penelitian menunjukkan bahwa keterbukaan informasi publik di Kabupaten Bantul sudah sangat baik.

$$
\text { Berdasarkan hasil penelitian }
$$

Implementasi Keterbukaan Informasi Publik di Kabupaten Bantul, rata-rata implementasi Keterbukaan Informasi Publik dari 10 Badan Publik di Kabupaten Bantul sebesar 88,4\% (sangat baik). Sebanyak 2 Badan Publik masuk dalam kategori baik dengan presentase 77\%, 5 Badan Publik masuk dalam kategori sangat baik dengan presentase di atas $80 \%$, dan 3 Badan Publik mencapai nilai sempurna yaitu sebesar $100 \%$ dengan kategori sangat baik. Hal ini menjukkan bahwa sebagian besar dari peubah yang diamati dalam penelitian ini yaitu profil badan publik, ringkasan program/kegiatan yang sedang dijalankan, informasi kinerja badan publik, ringkasan laporan keuangan, ringkasan akses informasi publik, informasi tentang peraturan, keputusan dan atau kebijakan yang mengikat dan berdampak bagi publik, informasi tentang tata cara memperoleh informasi publik, informasi tentang tata cara pengaduan mengenai penyalahgunaan wewenang, informasi tentang pengumuman pengadaan barang dan jasa, serta informasi tentang prosedur peringatan dini dan evakuasi telah diumumkan secara berkala melalui website resmi Badan Publik.

Implementasi Keterbukaan Informasi Publik pada Dinas Kesehatan Kabupaten Bantul mendapat poin sebesar 23 atau $77 \%$ (Baik). Kategori informasi Kinerja badan publik, Ringkasan laporan keuangan, Informasi tentang peraturan, keputusan dan atau kebijakan yang mengikat dan berdampak bagi publik, Informasi tentang tata cara Publisher : UMSU Press 
memperoleh informasi publik, Informasi tentang tata cara pengaduan mengenai penyalahgunaan wewenang, Informasi tentang pengumuman pengadaan barang dan jasa, Informasi tentang prosedur peringatan dini dan evakuasi, sudah tersedia secara lengkap dan dapat diakses secara online melalui website resmi Dinas Kesehatan Kabupaten Bantul yaitu: https://dinkes.bantulkab.go.id. Hanya saja masih ada kategori informasi yang belum dapat diakses secara lengkap seperti pada Profil badan publik, dan ringkasan program/kegiatan yang sedang dijalankan.

Pada profil badan publik belum tersedia informasi mengenai laporan harta kekayaan bagi pejabat Negara yang wajib melakukannya yang telah diperiksa, diverifikasi dan telah dikirimkan oleh KPK ke badan publik, kemudian pada informasi mengenai ringkasan program/kegiatan yang sedang dijalankan, aspek yang belum terpenuhi adalah informasi tentang penerimaan calon peserta didik pada badan publik penyelenggaraan kegiatan pendidikan umum. Adapun informasi mengenai ringkasan akses informasi publik dengan 4 indikator penilaian belum tersedia.

Implementasi Keterbukaan Informasi Publik pada Dinas Tenaga Kerja dan Transmigrasi Kabupaten Bantul mendapat poin sebesar 30 atau 100\% (Sangat baik). Pada 10 kategori informasi yang menjadi poin penilaian, semua informasi sudah tersedia E-ISSN: 2580-6955 secara lengkap dan dapat diakses secara online melalui website resmi Disnakertrans Kabupaten Bantul yaitu: https://disnakertrans.bantulkab.go.id/.

Berdasarkan hasil wawancara dengan Petugas PPID, Dinas Tenaga Kerja dan Transmigrasi Kabupaten Bantul, selama ini sudah berupaya maksimal untuk memberikan informasi kepada publik, sebagaimana salah satu hak rakyat adalah hak untuk tahu. Dengan demikian hasil yang sangat baik ini diperoleh dari keseriusan dan kerjasama semua pihak.

Implementasi Keterbukaan Informasi Publik pada Dinas Perdagangan Kabupaten Bantul mendapat poin sebesar 30 atau $100 \%$ (Sangat baik). Pada 10 kategori informasi yang menjadi poin penilaian, semua informasi sudah tersedia secara lengkap dan dapat diakses secara online melalui website resmi Dinas Perdagangan Kabupaten Bantul yaitu: https://perdagangan.bantulkab.go.id. Berdasarkan hasil wawancara dengan Petugas PPID, Dinas Perdagangan Kabupaten Bantul, dalam rangka menyediakan akses informasi kepada publik, segala informasi di website terus diperbaharui, dan terus berkomitmen untuk memberikan yang terbaik kepada publik. Badan Perencanaan Pembangunan Daerah (BAPPEDA) Kabupaten Bantul.

Implementasi Keterbukaan Informasi Publik pada BAPPEDA Kabupaten Bantul mendapat poin sebesar 26 atau 87\% (Sangat Baik). Kategori informasi Profil badan publik, Ringkasan program/kegiatan yang Publisher : UMSU Press 
sedang dijalankan, Informasi Kinerja badan publik, Ringkasan laporan keuangan, Informasi tentang tata cara memperoleh informasi publik, Informasi tentang pengumuman pengadaan barang dan jasa sudah tersedia secara lengkap dan dapat diakses secara online melalui website resmi BAPPEDA Kabupaten Bantul yaitu: https://bappeda.bantulkab.go.id/. Hanya saja masih ada kategori informasi yang belum dapat diakses secara lengkap seperti pada ringkasan akses informasi publik, Informasi tentang peraturan, keputusan dan atau kebijakan yang mengikat dan berdampak bagi publik, Informasi tentang tata cara pengaduan mengenai penyalahgunaan wewenang dan Informasi tentang prosedur peringatan dini dan evakuasi.

Implementasi Kebijakan Keterbukaan Informasi Publik pada Dinas Pertanahan dan Tata Ruang Kabupaten Bantul mendapat poin sebesar 26 atau $87 \%$ (sangat baik). Profil Badan Publik; Ringkasan program/kegiatan yang sedang dijalankan; Informasi kegiatan badan publik; Ringkasan laporan keuangan; Ringkasan akses informasi publik; Informasi tentang peraturan keputusan, dan atau kebijakan yang mengikat dan berdampak bagi publik, dan Informasi tentang pengumuman pengadaan barang dan jasa sudah tersedia dan dapat diakses secara online melalui website resmi Dinas Pertanahan dan Tata Ruang Kabupaten Bantul yaitu https://dptr.bantulkab.go.id/. Hanya saja, ada E-ISSN: 2580-6955
3 indikator yang belum dapat diakses melalui website diantaranya Penyalahgunaan wewenang dan pelanggaran yang dilakukan pejabat; Penyalahgunaan wewenang dan pelanggaran yang dilakukan mendapat izin atau melakukan perjanjian kerja dengan badan publik; dan Informasi tentang prosedur peringatan dini dan evakuasi keadaan darurat.

Sebagai Dinas yang bertugas di bidang komunikasi dan informatika, Dinas Kominfo Kabupaten Bantul telah mengimplementasikan Kebijakan Keterbukaan Informasi Publik dengan sangat baik dengan mendapat poin sebesar 30 (100\%). Hal ini menunjukkan seluruh kategori dan indikator berdasarkan informasi yang wajib disediakan dan diumumkan secara berkala telah tersedia dan dapat diakses oleh masyarakat secara online melalui website Dinas Kominfo Kabupaten Bantul yaitu https://diskominfo.bantulkab.go.id/.

Berdasarkan hasil wawancara yang dilakukan kepada PPID Dinas Kominfo Kabupaten Bantul, mereka sangat memahami regulasi Infomasi Publik dalam UU Nomor 14 Tahun 2008 tentang Keterbukaan Informasi Publik (UU KIP). Tidak hanya itu, mereka juga melakukan pembinaan kepada Badan Publik di Kabupaten Bantul hingga ke tingkat kecamatan, agar UU Keterbukaan Informasi Publik dalam website ini dapat diimplementasikan dengan baik.

Implementasi Kebijakan Keterbukaan Informasi Publik pada Dinas Kependudukan Publisher : UMSU Press 
dan Pencatatan Sipil Kabupaten Bantul mendapat poin sebesar 25 atau $83 \%$ (sangat baik). Profil Badan Publik; Ringkasan program/kegiatan yang sedang dijalankan; Informasi kegiatan badan publik; Ringkasan laporan keuangan; Ringkasan akses informasi publik; Informasi tentang peraturan keputusan, dan atau kebijakan yang mengikat dan berdampak bagi publik; dan informasi tentang prosedur peringatan dini dan evakuasi keadaan darurat sudah tersedia dan dapat diakses secara online melalui website resmi Dinas Kependudukan dan Pencatatan Sipil Kabupaten Bantul yaitu https://disdukcapil.bantulkab.go.id/. Hanya saja, ada 4 indikator yang belum dapat diakses melalui website diantaranya daftar asset dan investasi; penyalahgunaan wewenang dan pelanggaran yang dilakukan pejabat; penyalahgunaan wewenang dan pelanggaran yang dilakukan mendapat izin atau melakukan perjanjian kerja dengan badan publik; dan informasi tentang pengumuman pengadaan barang atau jasa. Berdasarkan hasil wawancara dan konfirmasi dengan petugas PPID Dinas Kependudukan dan Pencatatan Sipil Kabupaten Bantul, beberapa dokumen yang belum dapat diakses melalui website tersebut sesungguhnya sudah tersedia, akan tetapi belum dipublikasikan ke website.

Implementasi Kebijakan Keterbukaan Informasi Publik pada Dinas Lingkungan Hidup Kabupaten Bantul mendapat poin E-ISSN: 2580-6955 sebesar 23 atau $77 \%$ (Baik). Profil Badan Publik; Ringkasan program/kegiatan yang sedang dijalankan; Informasi kegiatan badan publik; Ringkasan laporan keuangan; Ringkasan akses informasi publik; Informasi tentang peraturan keputusan, dan atau kebijakan yang mengikat dan berdampak bagi publik, informasi tentang tata cara memperoleh informasi public; informasi tentang tata cara pengaduan mengenai penyalahgunaan wewenang; dan Informasi tentang pengumuman pengadaan barang dan jasa sudah tersedia dan dapat diakses secara online melalui website resmi Dinas Lingkungan Hidup Kabupaten Bantul yaitu https://dlh.bantulkab.go.id/._Hanya saja, ada beberapa indikator yang belum dapat diakses melalui website diantaranya jumlah pemohon informasi publik yang diterima, waktu yang diperlukan dalam memenuhi setiap permohonan informasi publik, jumlah permohonan informasi publik yang dikabulkan baik sebagian maupun seluruhnya dan permohonan informasi publik yang ditolak, alasan penolakan permohonan informasi publik; tata cara memperoleh informasi publik; tata cara pengajuan serta proses penyelesaian sengketa informasi publik; dan informasi tentang prosedur peringatan dini dan evakuasi keadaan darurat. Berdasarkan hasil wawancara dengan PPID. Implementasi Kebijakan Keterbukaan Informasi Publik pada Badan Pusat Statistik Kabupaten Bantul mendapat poin sebesar 25 Publisher : UMSU Press 
atau $83 \%$ (sangat baik). Profil Badan Publik; Ringkasan program/kegiatan yang sedang dijalankan; Informasi kegiatan badan publik; Ringkasan laporan keuangan; Informasi tentang peraturan keputusan, dan atau kebijakan yang mengikat dan berdampak bagi publik, dan Informasi tentang pengumuman pengadaan barang dan jasa sudah tersedia dan dapat diakses secara online melalui website resmi Badan Pusat Statistik Kabupaten Bantul yaitu https://bantulkab.bps.go.id/. Hanya saja, ada beberapa indikator yang belum dapat diakses melalui website diantaranya waktu yang diperlukan dalam memenuhi setiap permohonan informasi publik; penyalahgunaan wewenang dan pelanggaran yang dilakukan pejabat; penyalahgunaan wewenang dan pelanggaran yang dilakukan mendapat izin atau melakukan perjanjian kerja dengan badan publik; dan Informasi tentang prosedur peringatan dini dan evakuasi keadaan darurat.

Berdasarkan hasil konfirmasi dengan PPID Badan Pusat Statistik Kabupaten Bantul, beberapa dokumen tersebut sudah tersedia, akan tetapi belum dipublikasikan ke website dan mereka berkomitmen untuk segera mempublikasikan.

Implementasi Kebijakan Keterbukaan Informasi Publik pada Pengadilan Agama Kabupaten Bantul mendapat poin sebesar 27 atau 90\% (sangat baik). Profil Badan Publik; Ringkasan program/kegiatan yang sedang dijalankan; Informasi kegiatan badan publik; E-ISSN: 2580-6955 ringkasan laporan keuangan; Ringkasan akses informasi publik; informasi tentang peraturan keputusan, dan atau kebijakan yang mengikat dan berdampak bagi publik, dan Informasi tentang pengumuman pengadaan barang dan jasa sudah tersedia dan dapat diakses secara online melalui website resmi Pengadilan Agama Kabupaten Bantul yaitu https://www.pa-bantul.go.id/. Hanya saja, ada beberapa indikator yang belum dapat diakses melalui website diantaranya penyalahgunaan wewenang dan pelanggaran yang dilakukan pejabat; penyalahgunaan wewenang dan pelanggaran yang dilakukan mendapat izin atau melakukan perjanjian kerja dengan badan publik; dan Informasi tentang prosedur peringatan dini dan evakuasi keadaan darurat. Berdasarkan hasil konfirmasi dengan PPID, beberapa dokumen tersebut sudah tersedia, akan tetapi belum dipublikasikan ke website. Kekurangan dokumen yang belum bisa diakses oleh masyarakat secara online akan segera diunggah ke website Pengadilan Agama Kabupaten Bantul.

Seluruh Badan Publik di Kabupaten Bantul berkomitmen untuk segera mengunggah informasi yang masih belum tersedia di website. Pada umumnya dokumen sudah dimiliki akan tetapi belum diunggah ke website resmi. Berdasarkan hasil wawancara dengan Badan Publik, salah satu faktor yang menjadi kendala dalam Implementasi Keterbukaan Informasi Publik adalah Sumber Daya Manusia. Beberapa badan publik masih 
kekurangan SDM yang memiliki keahlian dalam pengelolaan informasi khususnya website dan media sosial lainnya. Hal ini mungkin akan menghambat, seperti yang disampaikan Awang (2010:42), bahwa kurangnya sumber daya tentu akan menghambat implementasi kebijakan yang akan atau sedang dijalankan.

Hal ini selaras juga dengan temuan pada penelitian Hariyanti (2018:127-139), bahwa Faktor Komunikasi, Sumber Daya, Disposisi dan Struktur Birokrasi sudah cukup terpenuhi dengan baik, hanya saja terdapat kendala pada faktor sumber daya yaitu kurangnya jumlah staf seksi pelayanan informasi publik yang merupakan implementor dalam kebijakan tersebut, selain itu belum terpenuhinya fasilitas penunjang seperti kamera profesional. Meskipun jumlah staf yang kurang memadai, implementor memiliki keahlian dalam menjalankan kebijakan tersebut yaitu mampu mengoperasikan website dan juga media sosial sebagai sarana menyebarluaskan informasi publik.

Dengan implementasi keterbukaan informasi publik yang tinggi, penyelenggaraan pemerintahan dan berbagai kebijakan publik di Kabupaten Bantul menjadi lebih transparan, meminimalkan terjadinya praktik korupsi, dan tingkat kepercayaan masyarakat semakin meningkat. Hal ini selaras dengan konsep transparansi menurut Kristiyanto (2016), bahwa E-ISSN: 2580-6955 pemerintahan yang bersifat terbuka pun dapat meminimalkan terjadinya praktik korupsi, hal ini disebabkan korupsi umumnya tumbuh dan berkembang pada rezim ketertutupan. Konsep transparansi dan informasi tidak saja berkaitan erat dengan akuntabilitas tetapi juga dengan rule of law pada umumnya.

Hasil penelitian juga menunjukkan bahwa Badan Publik semakin menyadari bahwa informasi publik adalah hak yang dimiliki masyarakat, sehingga penting untuk diperhatikan. Hal ini sesuai dengan apa yang disampaikan Budhirianto (2014), bahwa informasi publik diakses dengan adanya hak yang dimiliki oleh masyarakat. hak untuk mengakses informasi publik dapat dilakukan sesuai dengan kaidah perundang-undangan yang berlaku. Badan Publik di Kabupaten Bantul juga berkomitmen untuk memberikan pelayanan kepada masyarakat dengan sebaiksebaiknya kepada masyarakat, sehingga mereka terus melakukan perbaikan dalam penyediaan sarana prasarana pelayanan khususnya website. Hal ini selaras dengan apa yang disampaikan Indah dan Hariyati (2018), bahwa dengan membuka akses publik terhadap informasi diharapkan Badan Publik semakin termotivasi untuk bertanggung jawab terhadap tugas dan fungsinya serta selalu berorientasi pada pelayanan kepada masyarakat dengan sebaik-baiknya.

Berdasarkan informasi yang didapatkan dari website Badan Publik Kabupaten Bantul, masyarakat dapat Publisher : UMSU Press 
mengajukan permohonan informasi ke Badan

Publik secara online dan menerima informasi yang dibutuhkan dengan cepat. Hal ini selaras dengan informasi yang disampaikan Nupikso (2015: 114), bahwa salah satu asas dalam UU KIP adalah setiap informasi publik harus dapat diperoleh pemohon dengan cepat, tepat waktu, biaya ringan, dan cara sederhana. Hal ini mengandung arti bahwa badan publik di Kabupaten Bantul telah menyediakan sarana dan prasarana yang memadai agar masyarakat dapat mengakses informasi publik sesuai dengan asas tersebut, salah satunya melalui website resmi.

Dengan adanya kompetisi antar Badan Publik berkaitan dengan Keterbukaan Informasi Publik yang diselenggarakan oleh Dinas Komisi dan Informasi Kabupaten Bantul, Badan Publik juga semakin termotivasi untuk melakukan pelaporan dengan baik, terus melakukan penyempurnaan website, dan secara berkala mengunggah informasi ke website resmi.

\section{Penutup}

$$
\text { Berdasarkan hasil analisis }
$$

Keterbukaan Informasi Publik di Kabupaten Bantul, rata-rata implementasi Keterbukaan Informasi Publik dari 10 Badan Publik di Kabupaten Bantul sebesar 88,4\% (sangat baik). Sebanyak 2 Badan Publik masuk dalam kategori baik dengan presentase $77 \%, 5$ Badan Publik masuk dalam kategori sangat baik dengan presentase di atas $80 \%$, dan 3
Badan Publik mencapai nilai sempurna yaitu sebesar $100 \%$ dengan kategori sangat baik. Hal ini menunjukkan bahwa badan publik di Kabupaten Bantul telah menyediakan sarana dan prasarana yang memadahi agar masyarakat dapat mengakses informasi publik sesuai dengan asas UU KIP, khususnya melalui website resmi.

Sebagian besar peubah yang diamati dalam penelitian ini telah diumumkan secara berkala melalui website resmi Badan Publik, diantaranya profil badan publik, ringkasan program/kegiatan yang sedang dijalankan, informasi kinerja badan publik, ringkasan laporan keuangan, ringkasan akses informasi publik, informasi tentang peraturan, keputusan dan atau kebijakan yang mengikat dan berdampak bagi publik, informasi tentang tata cara memperoleh informasi publik, informasi tentang tata cara pengaduan mengenai penyalahgunaan wewenang, informasi tentang pengumuman pengadaan barang dan jasa, serta informasi tentang prosedur peringatan dini dan evakuasi.

\section{Daftar Pustaka}

Arikunto, Suharsimi. 2010. Prosedur Penelitian : Suatu Pendekatan Praktik. Jakarta : Rineka Cipta

Arliman, Laurensius. 2018. "Implementasi Keterbukaan Informasi Publik untuk mendukung Kinerja Aparatur Sipil Negara yang Profesional," Jurnal Cendekia Hukum, 3 (2), 138-152. 
Awang, Azam. (2010). Implementasi Pemberdayaan Pemerintah Desa. Yogyakarta: Pustaka Pelajar.

Budhirianto, S. (2014). "PPID dan transfer informasi dalam perspektif keterbukaan informasi publik di Jawa Barat," Jurnal Observasi, 12 (1), 1-10.

Febriananingsih, N. (2012). "Keterbukaan Informasi Publik dalam Pemerintahan Menuju Tata Pemerintahan yang Baik," Jurnal Rechtsvinding, 1 (1), 135-156.

Indah, T., \& Hariyanti, P. (2018). "Implementasi Kebijakan Keterbukaan Informasi Publik pada Dinas Kominfo Kota Tasikmalaya," Jurnal Komunikasi, 12 (2), 127-140.

Kadji, Yulianto. 2015. Formulasi dan Implementasi Kebijakan Publik. Gorontalo: UNG Press Gorontalo.

Koentjoro. 2010. Metode Penelitian Kualitatif untuk Ilmu-Ilmu Sosial. Jakarta: Salemba Humanika.

Kristiyanto, E. N. (2016). "Urgensi Keterbukaan Informasi dalam Penyelenggaraan Pelayanan Publik," Jurnal Penelitian Hukum De Jure, 16 (2), 231.
Nupikso, D. (2015). "Implementasi Keterbukaan Informasi Publik Dalam Website Pemerintah Daerah," Jurnal Iptek-Kom, 17(2), 113-128.

Nurdiansyah, Edwin. (2016). "Keterbukaan informasi publik sebagai upaya mewujudkan transparansi bagi masyarakat," Jurnal Bhineka Tunggal Ika, 3(2), 147-151.

Pambayun, K. G. (2017). “Analisis Implementasi Kebijakan Keterbukaan Informasi Publik Pada Badan Perpustakaan Dan Kearsipan Daerah Provinsi Jawa Barat," Jurnal Politik Pemerintahan Dharma Praja, 10(1), 97-108.

Setiaman, A., Sugiana, D., \& Mahameruaji, J. N. (2013). "Implementasi Kebijakan Keterbukaan Informasi Publik," Jurnal Kajian Komunikasi, 1(2), 196-205.

Suryabrata, Sumadi. 2013. Metodologi Penelitian. Jakarta: PT Rajagrafindo Persada

Undang undang Nomor 14 Tahun 2008 tentang Keterbukaan Informasi Publik 